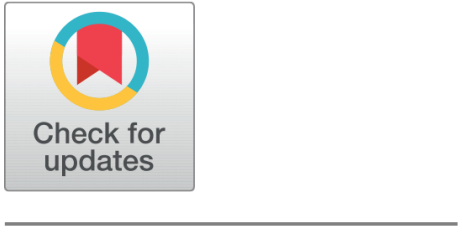

open ACCESS

Received: 09.04.2021

Accepted: 15.07.2021

Published: 07.09.2021

Citation: Packialakshmi K, Varghese LS, Thenesha K (2021) Reading Habits in Digital Era during Lockdown among Adolescent. Indian Journal of Science and Technology 14(29): 2420-2426. https ://doi.org/10.17485/IJST/v14i29.608

* Corresponding author.

lakshmikpackia@gmail.com

Funding: None

Competing Interests: None

Copyright: (c) 2021 Packialakshmi et al. This is an open access article distributed under the terms of the Creative Commons Attribution License, which permits unrestricted use, distribution, and reproduction in any medium, provided the original author and source are credited.

Published By Indian Society for Education and Environment (iSee)

ISSN

Print: 0974-6846

Electronic: 0974-5645

\section{Reading Habits in Digital Era during Lockdown among Adolescent}

\author{
K Packialakshmi ${ }^{1 *}$, Liji Sara Varghese ${ }^{1}$, K Thenesha $^{1}$ \\ 1 Assistant Professor, Faculty of Nursing, Dr MGR Educational and Research Institute, \\ Chennai, India
}

\section{Abstract}

Objectives : To assess the reading habits in digital era during COVID-19 lockdown period and to find the association between reading habits with selected demographic variables. Methods: A descriptive study design was adopted among 300 undergraduate students of Chennai, India using three tools such as Reading Attitude Scale, Self-Report Habit Index Questionnaire and Self-structured questionnaire on Reading Habit in Digital Era. The data was collected by using Google Forms considering the surge in COVID-19. Findings: Most of the samples 132 (44\%) were reading newspaper during the lockdown. Many of the samples 114 (38\%) were using google classroom for their academic activity, 131 (44\%) samples were spending 1 to 3 hours per day for academic work. Half of the samples 151 (50.33\%) accepted that reading online increases access to information sources. LinkedIn is famous among UG students. The study concluded that the undergraduate students are interested in digital reading during this lockdown period. The undergraduate students spent most of their time in digital reading, and they are connected with their studies during lockdown. Novelty: Many review articles have been published in online learning and related to education. Due to Covid-19 pandemic, many are forced to be away from direct books and started online reading. Therefore, our current review article highlights reading habits among adolescent during lockdown.

Keywords: Key Word: Reading Habits; Reading Attitude; Digital Era; Reading Attitude Scale; SelfReport Habit Index Questionnaire; Lockdown; Adolescent

\section{Introduction}

On 11 March 2020, the WHO declared an outbreak of Novel Coronavirus (COVID-19) pandemic and repeated the call for countries to act immediately and increase responses to treatment, detection and reduction of transmission to save lives ${ }^{(1)}$.

COVID-19 is a pandemic disease that has widely affected the world. It makes a sudden twist in everyone's life, thereby challenges on different live spheres such as political, scientific, education, religious, economic, public health and so forth in the countries concerned ${ }^{(2)}$.

In view of the pandemic situation, on 25 March 2020, the Prime Minister of India announced that most commercial activities and mass gatherings, including schooling and public institutions, were locked down countrywide and social distancing was 
encouraged $^{(3)}$. As of 05 May 2021 in India, 47\% of new cases reported globally and 276 daily cases reported per million populations $^{(4)}$.

In the unusual circumstance of the century, it is vital to see how people adapt to the government's constraints due to the lockdown owing to the pandemic and the effects on their different habits. Staying at home for a long time may change lifestyles of many individuals. Moreover, it may even lead to boredom and redundancy. In other words, people spent many days indoors and it influence their daily routine. Learning was the basis for life pleasure and is closely connected to vocational effectiveness ${ }^{(5)}$.

In particular, the provision of information or news regarding the pandemic disease or the lockdown was essential. Reading is an entertainment that inspires thought and imagination. This means, in a period that they are essential, reading offers hybrid benefits of information and entertainment (Merga, 2017) ${ }^{(6)}$.

Today, in the $21^{\text {st }}$ Century, we are experiencing revolution of digital technology with easy access to internet, smart-board, e-newspaper, e-reading material. In upcoming days, we can expect a more number of students carry electronic gadgets, which may carry thousands of books instead of one or two books. With this rise of technology, e-readers benefited from that, however, the reading habits are also affected in general $^{(7)}$.

According to National Survey of India (2020), the literacy rate of India is $77.7 \%$. The report also shows that almost $4 \%$ of rural households and $23 \%$ of urban households had computers. Among 15-29 years, almost $24 \%$ were able to operate a computer in rural and $56 \%$ in urban areas ${ }^{(8)}$.

A survey on digital lifestyle found that $71 \%$ are e-readers, since $29 \%$ are purchasing physical books. (Sanika Diwanji, 2019) ${ }^{(9)}$. Reading habits had increased to $36 \%$ during lockdown comparatively $21 \%$ before lockdown. Since people working from home were forced to use internet for various purpose like work, education, entertainment etc. (Mahendra Kumar,2020) ${ }^{(10)}$.

In India, the pandemic is currently different from one place to another, in terms of mortality and infection spread. It is an opportunity to find out how people adapt their habits and routines while in the home. We think it is important to explore ways in which the pandemic situation could have been handled and to explore reading habits among adolescents during lockdown.

\subsection{Aim of the study}

The aim of the study is to find the reading habits among adolescents during lockdown period

\subsection{Objectives}

- to assess the reading habits in digital era during lockdown period among adolescent

- to find the association between reading habits with the selected demographic variables

\subsection{Reading Habit}

Reading habits of adolescents are closely associated with their emotional vocabulary. The learners who are frequent readers can produce more emotional words, than those who are less frequent in reading ${ }^{(11)}$.

Adolescent reading habits and preferences suggested that females read more digital. Better awareness of adolescent reading pattern will aid academicians and parents to guide teenagers reading habits ${ }^{(12)}$. A recent survey suggested that reading enjoyment has increased during lockdown from $47.8 \%$ to $55.9 \%$. Around $35 \%$ young adults agreed that their reading habits are improved during lockdown ${ }^{(13)}$.

\subsection{Reading Attitude}

Reading attitudes are defined as reading feelings by students that lead to read tasks being approached or avoided ${ }^{(14)}$. Adolescent attitude towards academic digital reading are positively associated whereas negative association with recreational digital reading ${ }^{(15)}$.

In the beginning, most pupils felt positive about reading but often negative attitudes towards reading are developed, according to Ofsted. This then leads to a ferocious strengthening circle in which students who fail to progress are widening the gap between their readings and their peers and thus hardening their negative attitudes ${ }^{(16)}$.

An exploratory study by Clark and De Zoysa shows that reading pleasure and reading attitudes were directly linked to the way they read and were indirectly linked to their readings. Young people had positive reading attitudes and most of them agreed it was important. In general, young people reading at or above their age levels are more positive about reading than young people reading below their age levels. Significantly more young people that read below the age level in comparison with more young people agree that it is more important for girls than for boys to read. Similarly, they are far less likely to agree with statements that reading is a life skill, and that reading tells them what they need or want to know ${ }^{(17)}$. 


\subsection{Reading Habit in Digital Era during Lockdown}

WHO Director-General Dr Tedros Adhanom Ghebreyesus highlighted that joy of reading can influence young adults, to reduce worries and developing hope. Read the World program initiated by International Publishers Association (IPA), the World Health Organization (WHO) and UNICEF in 2020, with the aim of upgrading the mental health of young minds. Hand in hand of it, across the world many authors provide extracts of their publications to millions of young readers ${ }^{(18)}$.

One of the effective strategies to overcome the emotional imbalance with healthy activities can be by developing appropriate reading habit. Hence, medical and health experts of government of India started motivating citizens to focus on reading during lockdown ${ }^{(19)}$. The latest report of Amazon China concluded that $70 \%$ readers agreed that they read more books during lockdown ${ }^{(20)}$.

\section{Materials and Methods}

\subsection{Design of the study}

This study focuses on reading habits in digital era during lockdown period among adolescent at selected colleges in Chennai. The descriptive survey design was adopted due to the spread of the population of the study.

\subsection{Sample and sampling technique}

Total of 300 responses were collected from undergraduate students of selected colleges in Chennai, who aged 17 to 19 years. Non - probability purposive sampling technique was adopted. During selection of samples, verified the inclusive as well as exclusive criteria. The inclusive criteria included the students who can read and understand English and who have internet accessibility.

\subsection{Instruments}

The tool consists of four sections:

Part A: Demographic Variables such as age, gender, course of study, year of study, family income and area of residence.

Part B: Reading Attitude Scale. It consists of 7 items with 5-point Likert scale

Part C: Self-Report Habit Index Questionnaire. It consists of 5 items with 5-point Likert scale ranging from strongly disagrees to strongly agree.

Part D: Reading Habit in Digital Era. It is a self-structured questionnaire which consists of 11 items.

\subsection{Data collection method}

Ethical clearance was obtained from Institutional Ethical Committee of ACS Medical College \& Hospital, Chennai. A formal informed consent was obtained from the study participants. The investigator collected the data using the e-generated tools through web. The link to the web-based questionnaire was generated in the month of July, 2020 and was shared on respondents on WhatsApp. Data was collected for four weeks between the months of July, 2020 and August, 2020 and an intermittent followup and reminder was given to the respondents

\subsection{Data analysis}

The descriptive statistics, frequency count, simple percentage and inferential statistics were used to analyse the collected data.

\section{Results and Discussion}

The survey responses are analysed with descriptive and inferential statistics. The centre of the work is to analyse the reading habit of adolescent in the digital era during the lockdown of COVID - 19 pandemics. The solitary purpose of the study was to find the change of reading habit among undergraduate students. Three hundred undergraduate students responded to the online questionnaire.

\subsection{Socio - demographic factors associated with reading habit}

More than half of the samples 161 (54\%) were from 20-22 years of age. Majority of the samples 226 (76\%) were female, more than half of the samples $179(60 \%)$ were from medical domain, 109 (36\%) were II year students, and nearly half of the samples 147 (49\%) were living in urban area. 
Table 1. Distribution of samples regarding reading activities

\begin{tabular}{|c|c|c|c|c|c|c|c|c|c|c|c|c|}
\hline \multirow[t]{2}{*}{$\begin{array}{l}\text { Sl. } \\
\text { No }\end{array}$} & \multirow[t]{2}{*}{ Questionnaire } & \multirow{2}{*}{$\begin{array}{l}\text { Almost } \\
\text { day } \\
\mathrm{n}\end{array}$} & \multirow{2}{*}{$\begin{array}{l}\text { every } \\
\%\end{array}$} & \multicolumn{2}{|c|}{$\begin{array}{l}\text { Once/Twice } \\
\text { week }\end{array}$} & $\mathrm{a}$ & \multicolumn{2}{|c|}{$\begin{array}{l}\text { Once/Twice } \\
\text { month }\end{array}$} & \multicolumn{2}{|c|}{$\begin{array}{l}\text { A few times } \\
\text { a year }\end{array}$} & \multicolumn{2}{|c|}{$\begin{array}{l}\text { Never or } \\
\text { hardly ever }\end{array}$} \\
\hline & & & & $\mathrm{n}$ & $\%$ & & $\mathrm{n}$ & $\%$ & $\mathrm{n}$ & $\%$ & $\mathrm{n}$ & $\%$ \\
\hline 1 & $\begin{array}{l}\text { Read on your own outside of college } \\
\text { subjects during the lockdown }\end{array}$ & 86 & 29 & 140 & 46 & & 44 & 15 & 18 & 6 & 12 & 4 \\
\hline 2 & $\begin{array}{l}\text { Read the newspaper during the lock- } \\
\text { down }\end{array}$ & 132 & 44 & 74 & 25 & & 37 & 12 & 18 & 6 & 39 & 13 \\
\hline
\end{tabular}

Table 2. Distribution of samples regarding reading habits

\begin{tabular}{|c|c|c|c|c|c|c|c|c|c|c|c|}
\hline \multirow[t]{2}{*}{$\begin{array}{l}\text { Sl. } \\
\text { No }\end{array}$} & \multirow[t]{2}{*}{ Questionnaire } & \multicolumn{2}{|c|}{$\begin{array}{l}\text { Almost } \\
\text { always }\end{array}$} & \multicolumn{2}{|c|}{$\begin{array}{l}\text { More } \\
\text { than } \\
\text { half the } \\
\text { time }\end{array}$} & \multicolumn{2}{|c|}{$\begin{array}{l}\text { About } \\
\text { half the } \\
\text { time }\end{array}$} & \multicolumn{2}{|c|}{$\begin{array}{l}\text { Less } \\
\text { than } \\
\text { half the } \\
\text { time }\end{array}$} & \multicolumn{2}{|c|}{$\begin{array}{l}\text { Never } \\
\text { or } \\
\text { hardly } \\
\text { ever }\end{array}$} \\
\hline & & $\mathrm{n}$ & $\%$ & $\mathrm{n}$ & $\%$ & $\mathrm{n}$ & $\%$ & $\mathrm{n}$ & $\%$ & $\mathrm{n}$ & $\%$ \\
\hline 1 & Reading habit helps me learn about myself in lockdown period & 112 & 38 & 88 & 29 & 67 & 22 & 23 & 8 & 10 & 3 \\
\hline 2 & Reading helps me to understand why people feel or act the way they do & 111 & 37 & 91 & 30 & 70 & 23 & 17 & 6 & 11 & 4 \\
\hline 3 & $\begin{array}{l}\text { I believe that reading will help me get ahead during lockdown when I am } \\
\text { no longer in college }\end{array}$ & 146 & 49 & 78 & 26 & 49 & 16 & 21 & 7 & 6 & 2 \\
\hline 4 & I can understand what I read in college subjects at home during lockdown & 99 & 33 & 83 & 28 & 80 & 27 & 22 & 7 & 16 & 5 \\
\hline 5 & I learn worthwhile things from reading books in lockdown & 107 & 36 & 100 & 33 & 60 & 20 & 23 & 8 & 10 & 3 \\
\hline
\end{tabular}

\subsection{Self-Report Habit Index Score among undergraduate students}

The lock-down isolates students from regular academic activities at home. However, many digital libraries afford remote access to students for accessing digital resources from home. The digital resources have inspired the students to read more content during lockdown days ${ }^{(21)}$, however among 300 samples, 19 (6\%) were reading frequently, $26(9 \%)$ samples were feeling as odd if they do not read something, 25 (8\%) considered reading as their daily routine and whereas $26(9 \%)$ were interested in reading from school age onwards.

Table 3. Distribution of Reading Habit in the Digital Era.

\begin{tabular}{|c|c|c|c|}
\hline Sl. No & Questionnaire & Frequency & Percentage \\
\hline \multirow{9}{*}{1.} & \multicolumn{3}{|c|}{ What are the items read most frequently by you, in online during the lock-down } \\
\hline & a) Newspaper & 43 & 14 \\
\hline & b) Magazine & 9 & 3 \\
\hline & c) Textbook & 22 & 7 \\
\hline & d) Novel & 26 & 8.5 \\
\hline & e) Email & 11 & 3.5 \\
\hline & f) Online information & 101 & 34 \\
\hline & g) Whats-app & 68 & 23 \\
\hline & h) Fitness & 20 & 7 \\
\hline \multirow{8}{*}{2.} & \multicolumn{3}{|c|}{ What is the most priority activity carried by you, when you are in online } \\
\hline & a) Listen to music & 93 & 31 \\
\hline & b) Play games & 44 & 15 \\
\hline & c) Look at photos & 9 & 3 \\
\hline & d) Shop online & 6 & 2 \\
\hline & e) Chat with friends & 75 & 25 \\
\hline & f) Check emails & 37 & 12 \\
\hline & g) Download the movies & 36 & 12 \\
\hline \multirow{5}{*}{3.} & What internet package us & & \\
\hline & a) VPN & 1 & 0.5 \\
\hline & b) Dial Up & 1 & 0.5 \\
\hline & c) $\mathrm{WiFi}$ & 41 & 14 \\
\hline & d) Mobile data & 244 & 81 \\
\hline
\end{tabular}




\begin{tabular}{|c|c|c|c|}
\hline \multicolumn{4}{|c|}{ Table 3 continued } \\
\hline & e) Hotspot & 8 & 2.5 \\
\hline & f) Broadband & 5 & 1.5 \\
\hline \multirow{5}{*}{4.} & Which type of internet facility you have? & & \\
\hline & a) $2 \mathrm{~GB}$ & 133 & 44 \\
\hline & b) $3 \mathrm{~GB}$ & 20 & 7 \\
\hline & c) $4 \mathrm{~GB}$ & 82 & 27 \\
\hline & d) Unlimited & 65 & 22 \\
\hline \multirow{6}{*}{5.} & Which electronic gadget do you use for onlin & & \\
\hline & a) Smart Phone & 249 & 83 \\
\hline & b) Laptop & 30 & 10 \\
\hline & c) Personal Computer & 3 & 1 \\
\hline & d) Tablet & 9 & 3 \\
\hline & e) Others & 9 & 3 \\
\hline \multirow{6}{*}{6.} & How much GB, did you spend per day? & & \\
\hline & a) $1 \mathrm{~GB}$ & 108 & 36 \\
\hline & b) $1.5 \mathrm{~GB}$ & 110 & 37 \\
\hline & c) $2 \mathrm{~GB}$ & 46 & 15 \\
\hline & d) $3 \mathrm{~GB}$ & 10 & 3 \\
\hline & e) Unlimited & 26 & 9 \\
\hline \multirow{5}{*}{7.} & How many hours you spend on accessing the & ity da & \\
\hline & a) Less than 1 hour & 61 & 20 \\
\hline & b) $1-3$ hours & 131 & 44 \\
\hline & c) $3-6$ hours & 62 & 21 \\
\hline & d) More than 6 hours & 46 & 15 \\
\hline \multirow{5}{*}{8.} & How many hours you spend apart from your & oy you & \\
\hline & a) Less than 1 hour & 68 & 23 \\
\hline & b) $1-3$ hours & 147 & 49 \\
\hline & c) $3-6$ hours & 56 & 19 \\
\hline & d) More than 6 hours & 29 & 10 \\
\hline \multirow{8}{*}{9.} & In which virtual platform, you are spending $n$ & demi & \\
\hline & a) Google Classroom & 114 & 38 \\
\hline & b) Zoom & 88 & 29 \\
\hline & c) Moodle & 1 & 1 \\
\hline & d) Google Meet & 30 & 10 \\
\hline & e) Whatsapp & 61 & 20 \\
\hline & f) MedWhiz LMS & 0 & 0 \\
\hline & g) Impartus Virtual classroom & 6 & 2 \\
\hline \multirow{7}{*}{10.} & The highest impact of Internet sources on you & & \\
\hline & a) Increases access to information sources & 151 & 50 \\
\hline & b) Increases use of Foreign source & 13 & 4 \\
\hline & c) Increases contact with worldwide readers & 20 & 7 \\
\hline & d) Increases time spend on online reading & 68 & 23 \\
\hline & e) Decreases reading of printed material & 29 & 10 \\
\hline & f) Decreases reading in local language & 19 & 6 \\
\hline
\end{tabular}

\subsection{Distribution of samples in professional network platform}

There are many professional network platforms that are available worldwide. Amongst these platforms, LinkedIn is the vast professional network platform. More than 610 million users from 200 countries and territories worldwide were in the world's largest professional network ${ }^{(22)}$. It was found out that $41(14 \%)$ were using LinkedIn professional network platform, 8 (3\%) were on Research Gate and 14 (5\%) were in both platforms. This indicates that LinkedIn is more popular among undergraduate students than Research Gate. 


\subsection{Mean and standard deviation of Reading attitude and reading habit in the digital era during lock down}

The Mean and standard deviation of Reading attitude and reading habit in the digital era during lock down were $27.3 \pm 4.89$ and $14.7 \pm 3.9$ respectively.

\subsection{Discussion}

In the present study, most of the samples $132(44 \%)$ were reading the newspaper during the lockdown. Nearly half of the samples 146 (49\%) believed that reading will help them to get ahead during lockdown when they were no longer in college.

Nonetheless, $51 \%$ of young people like reading, more than a third enjoy reading only a little while, while $10 \%$ don't really like reading. Whereas $18.8 \%$ of young people agreed strongly that reading is boring, while a quarter of people agreed strongly that they only read because they had to and major group disagreed strongly that they read only in class. On the other hand, $59 \%$ of young people strongly agreed to read $^{(17)}$.

The study results revealed that majority of the samples use 249(83\%) smartphone, 30(10\%) use laptop, 9(3\%) tablet and only $3(1 \%)$ use personal computer to read during the COVID-19 lockdown. This is similar to the findings of Ismail Olatunji Adeyemi (2021), the most common reading device among $97.8 \%$ respondents was phone. Whereas notebooks were read by $68.8 \%$ and computer/laptops was used to read by $54.1 \%{ }^{(23)}$.

The current research showed that many of the samples 114 (38\%) were using google classroom for their academic activity, 131 (44\%) samples were spending 1 to 3 hours per day for academic work. Nearly half of the samples 147 (49\%) were spending $1-3$ hours per day for other activities apart from college activities. A survey among teenagers at Indian Public School found that teenagers of both sexes spent $1-2$ hour, with a small sex difference $69 \%$ girls and $65 \%$ boys. Whereas $32 \%$ of the teenagers spent 2 to 3 hours in the Online Readings Platform ${ }^{(24)}$.

However, it was found that reading hours was improved during lockdown. Around 31.7\% of the respondents read between 1 to 2 hours/day, $39.2 \%$ read for 3 to 4 hours/day, $21.9 \%$ read for 5 to 7 hours/day and $7.2 \%$ read for more than 7 hours/day ${ }^{(24)}$. It was revealed that, as for reading out-of-class behaviour, most young people read out every day $(32 \%)$ or two to three times a week $(29 \%)$, while $7 \%$ do not read outside of class material ${ }^{(17)}$.

In the recent findings, half of the samples $151(50 \%)$ accepted reading on online as an increase access to information and among it LinkedIn was more famous among UG students. Various studies supported that majority read to gather information on current situation and it was stated by Ismail Olatunji Adeyemi (2021) that $86.5 \%$ Nigerians focused on reading to seek COVID -19 information. On other hand, $61.1 \%$ engaged in reading to meet their academic purposes ${ }^{(23)}$.

This present study result is consistent with the study conducted by Firima Zona Tanjung, et. al, (2017), concluded that the students were paying their attention on reading materials which are accessible in anytime and anywhere. Thus, the easy access to websites and other online sites enable them to keep their interest in reading ${ }^{(25)}$. In China, $95.9 \%$ adolescence has high prevalence of internet addiction by the high usage rate of social networks ${ }^{(26)}$.

Akanbi et al. reported that intensive internet psychosocial consequences were evident among undergraduate students. They were creating a new relationship through online platforms and spending more online time than going out ${ }^{(27)}$.

In contrast, studies conducted in Asian and Western countries showed that use of social networking sites became an online dominant activity, among adolescence ${ }^{(28,29)}$.

In the current research, the association between reading attitude and the demographic variable family income has statistically significant at $\mathrm{p}<0.05$ level. The present study findings are consistent with previous research work of Farooq Mubarak (2020), there was a strong positive association of income and education with levels of information communication technology penetration across the entire world ${ }^{(30)}$.

\section{Conclusion}

In view of the presumably continuing lockdown for weeks, the usual habits and well-being of the population should be monitored. The current study concluded that the undergraduate students are interested in digital reading during the COVID-19 lockdown period. They spent most of their time on digital reading, and also they are connected with their studies even though they are in lockdown.

\section{Recommendations}

As a part of technology advancement, the widespread use of technology among the students should come with increased awareness of the pros and cons of the technology. Research data can be collected in order to develop strategies to lessen the 
adverse effects and impacts of the unprecedented lockdown changes in people's lives. So, in the recent study, a more extensive research group is recommended.

\section{Limitations}

The current study was confined to the collection of online data and further research was only done on general reading and adolescent attitudes. The date was collected only from undergraduate students of a part of South India and sample is not nationally representative.

\section{References}

1) . 2021. Available from: https://www.who.int/india/emergencies/coronavirus-disease-(covid-19).

2) Mccloskey B, Zumla A, Ippolito G, Blumberg L, Arbon P, Cicero A. Mass gathering events and reducing further global spread of COVID-19: a political and public health dilemma. The Lancet. 2020;395(10230):1096-1099. Available from: https://www.thelancet.com/journals/lancet/article/ PIIS0140673620306814/fulltext.

3) India’s nationwide lockdown begins. . Available from: https://www.bbc.com/news/av/world-52044058.

4) Cdn.who.int. 2021. Available from: https://cdn.who.int/media/docs/default-source/wrindia/situation-report/india-situation-report-663bd1ad84-237d4f36-aacd-7e9953e65fc4.pdf?sfvrsn=173315f6_4.

5) Files.eric.ed.gov. 2021. Available from: https://files.eric.ed.gov/fulltext/EJ1245230.pdf.

6) Merga MK. What motivates avid readers to maintain a regular reading habit in adulthood? Australian Journal of Language and Literacy. 2017;40(2):146156. Available from: https://www.alea.edu.au/documents/item/1567.

7) Kahraman E, Daily Sabah. How technology is changing our reading habits. 2021. Available from: https://www.dailysabah.com/feature/2017/08/29/howtechnology-is-changing-our-reading-habits.

8) International Literacy Day 2020: Kerala most literate state in India, check rank-wise list. 2021. Available from: https:/www.hindustantimes.com/ education/international-literacy-day-2020-kerala-most-literate-state-in-india-check-rank-wise-list/story-IodNVGgy5hc7PjEXUBKnIO.html\#: : text=International\%20Literacy\%20Day\%202020.

9) Statista . India - sources of book consumption 2019. 2019. Available from: https://www.statista.com/statistics/978512/india-sources-of-bookconsumption/.

10) Kumar M, Dwivedi S. Impact of Coronavirus Imposed Lockdown on Indian Population and their Habits. International Journal of Science and Healthcare Research. 2020;5(2):88-97.

11) Reading habits and emotional vocabulary in adolescents. 2021. Available from: https://www.tandfonline.com/doi/full/10.1080/01443410.2020.1732874.

12) Loh CE, Sun B, Majid S. Do girls read differently from boys? Adolescents and their gendered reading habits and preferences. English in Education. 2019;54(2):174-190. doi:10.1080/04250494.2019.1610328.

13) National Literacy Trust. Children and young people's reading in 2020 before and during the COVID-19 lockdown . 2021.

14) Cooter R, Alexander J. Interest and attitude: Affective connections for gifted and talented readers. Reading World. 1984;24(1):97-102. Available from: https://doi.org/10.1080/19388078409557808.

15) Jang B, Ryoo J. Multiple dimensions of adolescents' reading attitudes and their relationship with reading comprehension. Reading and Writing. 2018;32(7):1769-1793. Available from: https://doi.org/10.1007/s11145-018-9926-6.

16) Publications.parliament.uk. 2021. Available from: https://publications.parliament.uk/pa/cm200405/cmselect/cmeduski/121/121.pdf.

17) Clark C, Zoysa SD, National Literacy Trust. Mapping the interrelationships of reading enjoyment, attitudes, behaviour and attainment. 2021.

18) IPA, WHO and UNICEF launch Read the World on International Children's Book Day to support children and young people in isolation. 2021. Available from: https://www.who.int/news/item/02-04-2020-ipa-who-and-unicef-launch-read-the-world-on-international-children-s-book-day-tosupport-children-and-young-people-in-isolation.

19) Mohfw.gov.in. 2021. Available from: https://www.mohfw.gov.in/pdf/MindingourmindsduringCoronaeditedat.pdf.

20) World Book and Copyright Day: COVID-19 shapes new reading habits. 2021. Available from: https://news.cgtn.com/news/2020-04-23/World-Bookand-Copyright-Day-COVID-19-shapes-new-reading-habits-PV3PbZHuCY/index.html.

21) Parikh K, Vyas P, Parikh SS. A Survey on Reading Habit of Library Users during COVID-19 Lockdown. Library Philosophy and Practice (e-journal). 2020;4216. Available from: https://digitalcommons.unl.edu/libphilprac/4216/.

22) 13 Awesome Professional Networking Alternatives to LinkedIn. 2021. Available from: https://www.searchenginejournal.com/linkedin-alternatives/ 297409/\#close.

23) Adeyemi IO. Influence of Covid-19 Lockdown on Reading Habit of Nigerians: A Case Study of Lagos State Inhabitants. Reading \& Writing Quarterly. 2021;37(2):157-168. Available from: https://doi.org/10.1080/10573569.2020.1857891.

24) Loan FA, Shah R. Survey of the literature reading habits and preferences of adolescents: A study of a public school in India. LIBRES. 2017;27(2):80-96.

25) Tanjung F, Ridwan R, Gultom U. Reading Habits In Digital Era: A Research On The Students In Borneo University. Language and Language Teaching Journal. 2017;20:147-157.

26) Xin M, Xing J, Pengfei W, Houru L, Mengcheng W, Hong Z. Online activities, prevalence of Internet addiction and risk factors related to family and school among adolescents in China. Addictive Behaviors Reports. 2018;7:14-18. Available from: https://doi.org/10.1016/j.abrep.2017.10.003.

27) Digitalcommons.unl.edu. 2021. Available from: https://digitalcommons.unl.edu/cgi/viewcontent.cgi?article=4970\&context=libphilprac.

28) Sampasa-Kanyinga H, Hamilton H. Social networking sites and mental health problems in adolescents: The mediating role of cyberbullying victimization. European Psychiatry. 2015;30(8):1021-1027.

29) Mak K, Lai C, Watanabe H, Kim D, Bahar N, Ramos M. Epidemiology of Internet Behaviors and Addiction Among Adolescents in Six Asian Countries. Cyberpsychology, Behavior, and Social Networking. 2014;17(11):720-728.

30) Mubarak F, Suomi R, Kantola SP. Confirming the links between socio-economic variables and digitalization worldwide: the unsettled debate on digital divide. Journal of Information, Communication and Ethics in Society. 2020;18(3):415-430. Available from: https://doi.org/10.1108/JICES-02-2019-0021. 